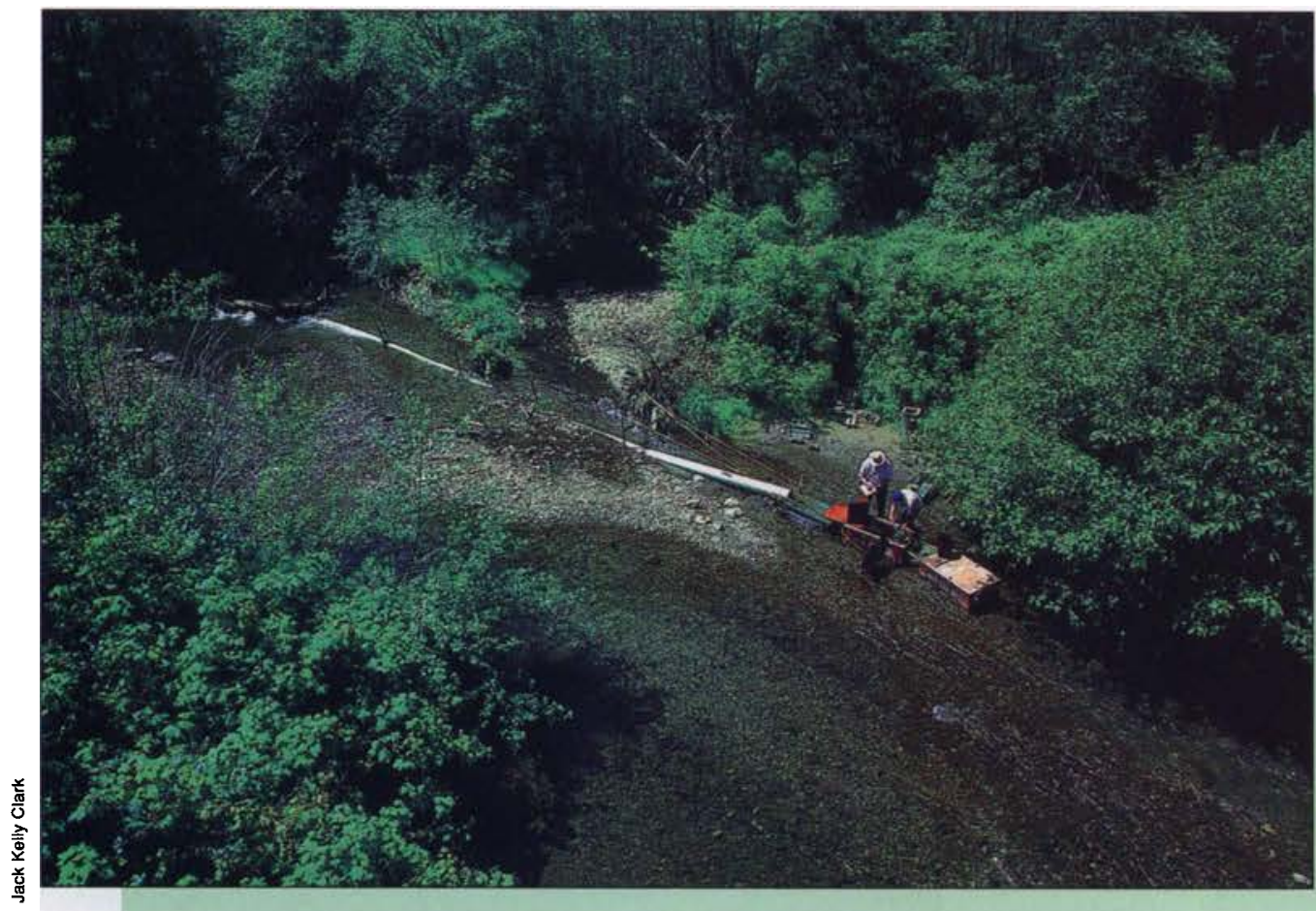

\section{Salmon restoration depends on improved habitat}

\author{
Jim Waldvogel
}

The streams and rivers that

California's salmon and trout call home during the freshwater portion of their life cycle have deteriorated over the past 50 years, resulting in decreases in the populations of these salmonids. Habitat deterioration and population changes are caused by natural occurrences (floods, fires, El Niños, drought, predators and changing ocean conditions); land-use practices (mining, timber harvest, highway construction, agriculture, grazing and urban development); increases in fishing effort; and major diversions of water resources and the damming of rivers.

Restoration of California's salmon and steelhead populations depends on the principle of managing natural stocks. The genetic diversity and population viability of individual runs of salmon requires that watershed and habitat conditions throughout a species range be restored or protected.

Improving degraded habitat, protecting stream quality, providing adequate clean water and flows, reducing fish harvest when appropriate and the long-term monitoring of fish runs are all part of the equation for restoring salmonid populations.

In recent years, the excellent returns of chinook salmon to the Sacramento and Klamath river systems have been direct reflections of improved ocean conditions and hatchery fish production. Natural salmon production, however, continues to decline in most watersheds.

In 1979, when I became Sea Grant Advisor for Del Norte County, the Smith River was in the process of be-

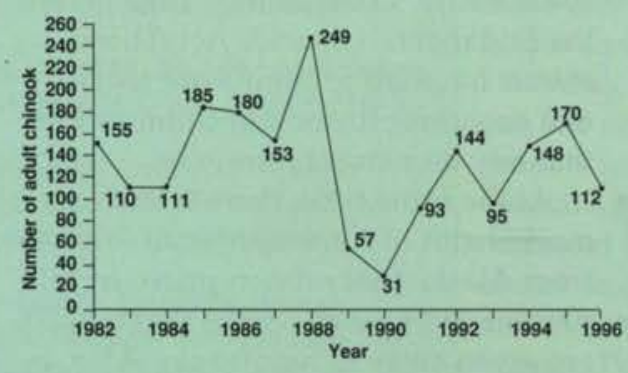

Fig. 1. Adult chinook spawning estimates for West Branch Mill Creek, Smith River (1980-1996).

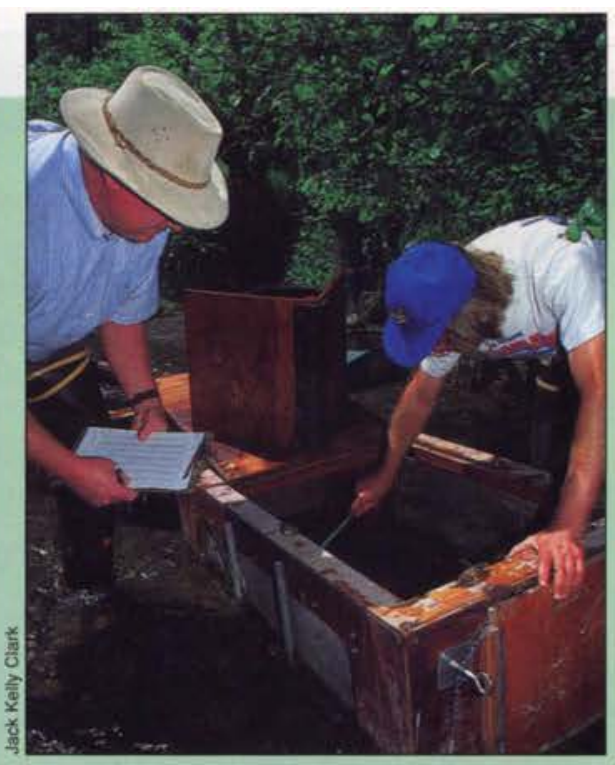

Instream traps are used to corral juvenile salmonids. Although small sections of old growth timber have been clear cut near West Branch Mill Creek, a major salmon spawning tributary of the Smith River, data collected over 17 years show natural fluctuations in a healthy salmon population.

ing designated a Wild and Scenic River. The Smith was described as an "excellent" salmon and steelhead stream; however, no evaluation criteria for natural salmonid stocks existed. Because of the need for a good research index stream (a stream that reflects healthy, natural fluctuations in a fish population), I initiated a 20 -year chinook salmon spawning escapement study in 1980 on West Branch Mill Creek, a major salmon spawning tributary of the Smith River.

The study section, on private timber land owned by the Rellim Redwood Company, is surrounded by lands that belong to the California State Park and Redwood National Park System. At the inception of the study, the West Branch watershed consisted of oldgrowth redwoods. Although small sections of old growth were clear cut between 1986 and 1995, the stream habitat has remained largely intact.

The 17 years of data collected on Mill Creek shows natural fluctuations in a healthy salmon population (fig. 1). The data reflect changes in natural environmental conditions (drought and flood) that have allowed the fish to withstand certain habitat changes. The study is also providing valuable information about coexisting coho and chum salmon populations. 


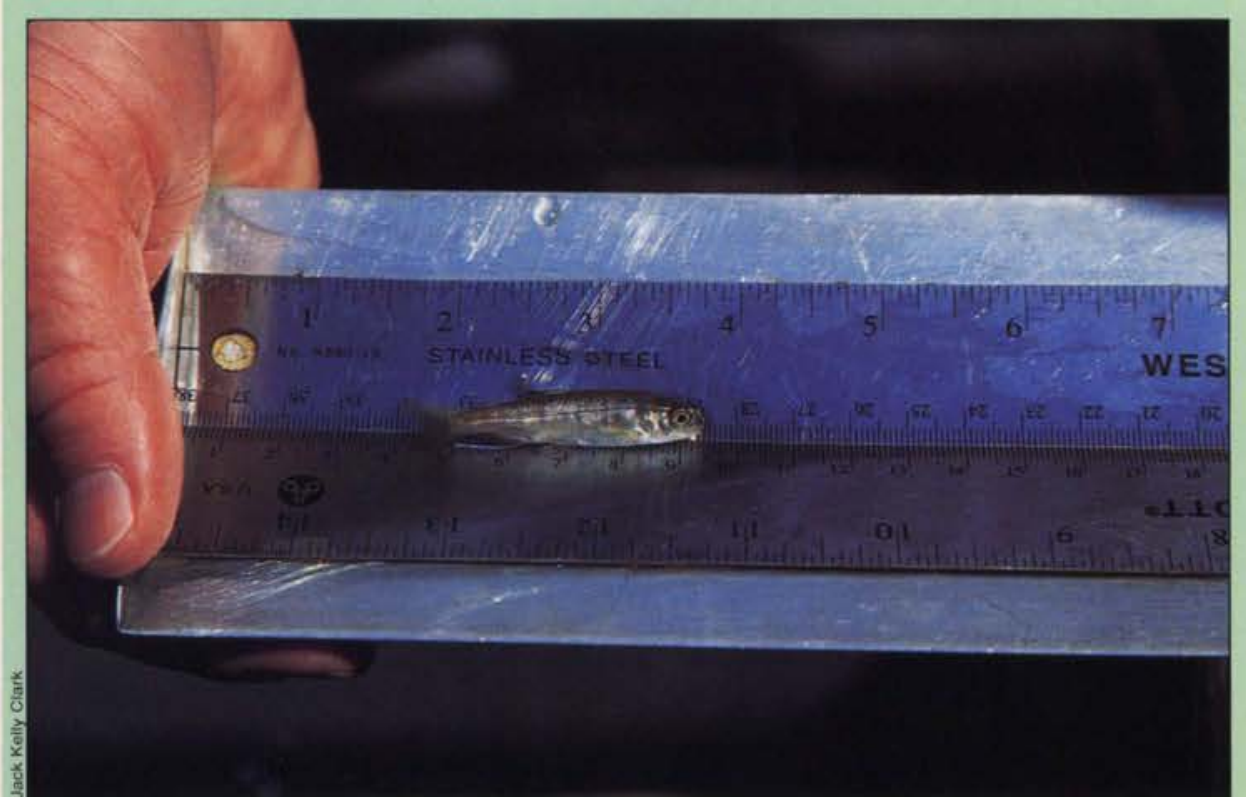

Samples of juvenile salmon and steelhead are netted out of the creek and measured to determine growth rates.

Although monitoring adult spawning salmon is a good way to gauge stock health, the real key to the health of salmonid habitat is juvenile salmon (smolt) production. During the past 5 years, Rellim biologists and I have monitored juvenile coho and chinook salmon production and compared it to adult spawning escapement. The results are just beginning to show a system in biological balance that can withstand fluctuations in adult returns and changing environmental conditions.

Restoring salmon habitat and increasing production also require educating landowners, enhancement groups and the public - those who will be responsible for covering the "costs" of improving and restoring salmon resources. In 1983, Northern California Sea Grant advisors organized the first statewide enhancement conference, which functioned as a valuable source of information about technical needs and project funding sources. These conferences continue as a primary information outreach to community-based restoration groups with guidance from the Salmonid Restoration Federation.

Extension Sea Grant staff have also coordinated programs for the SpringRun Chinook Salmon Workgroup on the Sacramento River. Habitat improvement actions taken by this group of farmers, landowners, fishers, forest managers, irrigation districts, environmentalists and resource agencies have delayed a potential Endangered Species Act (ESA) listing of this stock.

The recent and potential listings of salmon and steelhead species under the Federal ESA have brought home the need for community cooperation in restoring salmonid habitat and healthy stocks. Not only are these resources important to the economic viability of many communities, they are also symbols of our commitment to a healthy environment and biodiversity.

J. Waldvogel is the California/Oregon Sea Grant Extension Advisor, Del Norte and Curry counties.

\section{Further Reading}

Howard C. 1994. Juvenile Salmonid Monitoring on the East/West Branches of Mill Creek. Rellim Redwood Company Technical Report. $25 \mathrm{p}$.

Toole C. Waldvogel J. (eds.). 1989-1994. Proceedings of the 7 th-12th Salmonid Restoration Conferences. UC Cooperative Extension.

Waldvogel J. 1988. Fall Chinook Salmon Spawning Escapement Estimate for a Tributary of the Smith River, California. Second Interim Report (1980-87), UCSGEP-88-5. $22 \mathrm{p}$. continued from $p .27$

Over the past 25 years since the creation of Sea Grant, U.S. fisheries have moved from a development and Americanization phase to the current focus on issues of sustainability, ecosystem management, globalization, overcapitalization, bycatch of nontarget species, comanagement and allocation among user groups. Similarly, there has been a transition in Sea Grant research and extension focus from increasing fishers' production to concentrating on management-related issues. The commercial and recreational fishing industry, fishery managers, conservation organizations and concerned citizens are looking for innovative fishery-management approaches.

\section{California's situation}

Historically, California has had one of the world's most productive fisheries (Leet et al. 1992). Prevailing northwesterly winds and other factors combine to cause the upwelling of deep, cold nutrient-rich water to the sunlit surface. This leads to tremendous blooms of plankton (tiny plants and animals) that serve as the food base for the production of a large and diverse population of marine organisms. The intensity of this upwelling varies significantly, which makes it difficult to predict year-to-year variations in fish and shellfish populations (see page 36 ).

The sardine and tuna fisheries were California's most dominant during much of this century. Sardine landings grew to 700,000 tons during the 1930 s before collapsing in the late 1940s. The relative importance of the roles overfishing and changes in oceanographic conditions played in the collapse is still widely debated. After 40 years, sardine stocks have begun to recover and a small, conservatively managed fishery has resumed.

As the sardine fishery declined, the tropical tuna fleet expanded. Landings grew to more than 300 million pounds, worth more than all of the other fish landed in the state. However, by the early 1980 s, most of the tuna harvesting and processing industry had moved out of California. A combination of high labor costs, foreign competition 